\title{
PENGARUH RESPON PERUSAHAAN DALAM INVESTASI TEKNOLOGI INFORMASI TERHADAP KINERJA PERUSAHAAN FINANCE DI MANADO
}

\author{
Imelda Anggereiny Dajoh \\ Heince Wokas
}

\begin{abstract}
Financing companies are companies that provide or lend funds to consumers for the purchase of goods - goods such as vehicles, machinery, tools - and other heavy equipment - Other items purchased with a guarantee. Information technology investment is one of the company's assets that could improve the performance of the company in order to achieve company goals. Where technology is defined as the development and application of combining resources and knowledge that can help people solve the problem, while the information is a very important resource as a staple in maintaining the continuity of the company. So the information technology communication lines that carry data, voice and video that have been processed, so it is useful to take a decision that has meaning and is useful to achieve certain goals. Object of this study is a company - a finance company that is in Manado. Study authors are conducting the research is that information technology investments made by finance companies can improve the performance of the company. Based on the research results obtained by a simple linear regression equation between the value of information technology on performance is $Y=0.987 X$ $+\varepsilon$. This equation gives the sense that if the investment company's response to Information Technology (IT) increases 1 unit, then the performance of the company will increase by 0.987 units .. If the value of $\beta$ which is the correlation coefficient of the variable response to the company's IT investment $(X)$ of 0.987 means that if the response to the company's IT investment increase by 1 unit then the performance of the company will increase by 0.987 units
\end{abstract}

Keywords : system information, technology information investment, performance, finance company. 


\section{PENDAHULUAN}

Pada umumnya setiap perusahaan mempunyai tujuan - tujuan yang ingin dicapai. Salah satu tujuan utamanya adalah untuk memperoleh keuntungan dari usaha yang sedang dijalankan. Untuk mencapai tujuan utamanya adalah untuk memperoleh keuntungan dari usaha yang sedang dijalankan. Untuk mencapai tujuan tersebut diperlukan peningkatan efisiensi kerja serta pemilihan strategi yang diterapkan sesuai dengan kemampuan inti yang dimiliki serta kondisi eksternal perusahaan. Selain itu usaha yang dilakukan oleh perusahaan adalah melakukan investasi pada teknologi informasi. Mulyadi (1997) mengatakan bahwa teknologi maju, khususnya teknologi informasi, akan menyebabkan perubahan radikal maupun berkelanjutan pada organisasi. Dengan aplikasi teknologi maka organisasi akan mengalami perubahan sistem manajemen, dari sistem tradisional ke sistem manajemen kontemporer.

Kinerja organisasi selalu menjadi ukuran keberhasilan kegiatan organisasi sehingga diperlukan metode yang dapat mengukur kinerja tersebut (Kaplan dan Norton, 1996). Pentingnya pengukuran kinerja secara tepat, menurut Keats dan Hitt (1988) dikarenakan kinerja merupakan sebuah konsep yang sulit, baik definisi dan pengukurannya. Dengan mengetahui kondisi kinerja maka organisasi dapat melakukan revisi atas kebijakan-kebijakan yang tidak relevan sehingga pencapaian dimasa yang akan datang akan lebih baik. Sementara itu, Li dan Simerly (1998) mengatakan bahwa pengukuran kinerja merupakan sesuatu yang komplek dan merupakan tantangan besar bagi para peneliti karena sebagai sebuah konstruk, kinerja bersifat multidimensional Oleh karena itu, pengukuran kinerja dengan menggunakan dimensi pengukuran tunggal tidak mampu memberikan pemahaman yang komprehensif.

Perkembangan teknologi informasi memacu suatu cara baru dalam kehidupan, dari kehidupan dimulai sampai dengan berakhir, kehidupan seperti ini dikenal di Indonesia akan sangat mudah membantu pengembangan indutsri disektor keuangan ini, seperti perluasan cakupan usaha dengan membuka cabang usaha dengan membuka cabang usaha di daerah serta pertukaran informasi sesama perusahaan asuransi, perbankan, serta lembaga pembiayaan lainnya.

Masyarakat khususnya di Indonesia di bidang perniagaan atau perdagangan dan lembaga pembiayaan pada umumnya merupakan suatu kekuatan ekonomi yang ditunjang oleh kualitas sumber daya dalam meningkatkan produktivitas usaha dalam menghadapi persaingan di era globalisasi yang kompetitif. Tujuan akhir dari lembaga - lembaga ekonomi dalam masyarakat yaitu untuk membangun fondasi perekonomian dengan menghasilkan barang maupun jasa perusahaan sebagai salah satu komponen lembaga ekonomi, yang memiliki berbagai bentuk atau jenis, diantaranya perusahaan pembiayaan. Teknologi informasi akan membawa perusahaan pada kondisi yang menguntungkan yaitu kemudahan memasuki pasar, kemudahan dalam pelayanan terhadap konsumen dan terutama bagi kegiatan intern perusahaan itu sendiri. Dengan kemudahan tersebut maka perusahaan akan mampu meningkatkan kinerjanya. Investasi dalam teknologi informasi yang tepat akan menghasilkan suatu keunggulan kompetitif sehingga akan mampu mempertahankan dan meningkatkan kinerja perusahaan dalam bentuk output perusahaan, efisiensi, efektivitas, dan nilai perusahaan yang ditunjukan dengan nilai investasi perusahaan.

\section{LANDASAN TEORI}

Teknologi adalah satu ciri yang mendefinisikan hakikat manusia yaitu bagian dari sejarahnya meliputi keseluruhan sejarah. Teknologi, menurut Djoyohadikusumo (1994, 222) berkaitan erat dengan sains (science) dan perekayasaan (engineering). Dengan kata lain, teknologi mengandung dua dimensi, yaitu science dan engineering yang saling berkaitan satu sama lainnya. Sains mengacu pada pemahaman kita tentang dunia nyata sekitar kita, artinya mengenai ciri-ciri dasar pada dimensi ruang, tentang materi dan energi dalam interaksinya satu terhadap lainnya.

Sistem Informasi (SI) adalah kombinasi dari teknologi informasi dan aktivitas orang yang menggunakan teknologi itu untuk mendukung operasi dan manajemen. Dalam arti yang sangat luas, 
istilah sistem informasi yang sering digunakan merujuk kepada interaksi antara orang, proses algoritmik, data, dan teknologi. Dalam pengertian ini, istilah ini digunakan untuk merujuk tidak hanya pada penggunaan organisasi teknologi informasi dan komunikasi (TIK), tetapi juga untuk cara di mana orang berinteraksi dengan teknologi ini dalam mendukung proses bisnis. Ada yang membuat perbedaan yang jelas antara sistem informasi, dan komputer sistem TIK, dan proses bisnis. Sistem informasi yang berbeda dari teknologi informasi dalam sistem informasi biasanya terlihat seperti memiliki komponen TIK. Hal ini terutama berkaitan dengan tujuan pemanfaatan teknologi informasi. Sistem informasi juga berbeda dari proses bisnis. Sistem informasi membantu untuk mengontrol kinerja proses bisnis.

\section{KERANGKA PEMIKIRAN DAN HIPOTESIS}

\subsection{Tanggapan Perusahaan Terhadap Investasi Teknologi Informasi}

Saat ini penggunaan teknologi informasi di perusahaan semakin meningkat tidak hanya untuk operasional sehari - hari tetapi sudah pada proses membantu pengambilan keputusan namun demikian, perusahaan juga tidak bisa gegabah mengeluarkan investasi untuk mengimplementasikan teknologi informasi karena tentu saja harus memperhitungkan cost dan benefit yang dihasilkannya.

Dengan adanya perencanaan yang jelas, perusahaan bisa mengelola perusahaannya dengan baik sejak awal. Informasi memiliki nilai strategis guna memacu perkembangan bisnis dalam upaya unggul di dalam kompetisi. Kegiatan analisi bisnis yang akurat dan pengambilan keputusan yang tepat berdasarkan informasi semakin menentukan keberhasilan suatu dunia usaha.

Teknologi informasi sangat diperlukan dalam mewujudkan nilai strategis tersebut, akan tetapi biaya yang dibutuhkan biasanya tidaklah sedikit. Dengan demikian dalam menghitung biaya yang dikeluarkan dan keuntungan yang didapat dari suatu investasi teknologi informasi harus dilakukan dengan cermat.

Investasi teknologi informasi bukan sekedar untuk menunjukan prestise sebuah perusahaan. Memang kebutuhan teknologi informasi dalam perusahaan amat luas. Apliksi yang dibutuhkan amat beragam. Namun, bukan berarti semua kebutuhan tersebut harus dipenuhi dalam waktu yang bersamaan. Karenanya investasi informasi disetiap perusahaan haruslah menggunakan skala prioritas. Pilih kebutuhan mana yang dirasakan paling mendesak dan paling penting untuk jangka pendek dan menengah terlebih dahulu.

Perusahaan sangat merespon akan adanya investasi teknologi informasi karena teknologi informasi sangat diperlukan dalam mewujudkan tujuan perusahaan. Informasi juga memiliki nilai strategis guna memacu perkembangan bisnis dalam upaya unggul di dalam kompetisi.

\subsection{Tujuan dan Sasaran Evaluasi Kinerja}

Oleh Mangkunegara (2006:10) menyatakan bahwa tujuan evaluasi kinerja adalah "untuk memperbaiki atau meningkatkan kinerja organisasi melalui peningkatan kinerja dañ sumberdaya organisasi". Sasaran evaluasi kinerja yang dikemukakan oleh Anwar Membuat analisis kinerja dañ waktu yang lalu secara berkesinambungan dan periodik, baik kinerja karyawan maupun kinerja organisasi ; (2) Membuat evaluasi kebutuhan pelatihan dari pada karyawan melalui audit keterampilan dan pengetahuan ; (3) Menentukan sasaran dari kinerja yang akan datang dan memberikan tanggung jawaban perorangan serta kelompok ; (4) Menemukan potensi karyawan yang berhak memperoleh promosi.

\section{METODE PENELITIAN}

Jenis data yang digunakan dalam penelitian ini adalah data kualitatif yang dikuantitatifkan dengan menggunakan skala Likert Menurut Kuncoro (2003:124) jenis data dapat dibedakan menjadi 2 jenis, yaitu sebagai berikut: (a) Data kualitatif adalah data yang tidak dapat diukur dalam skala numerik. Namun karena dalam statik semua data harus dalam bentuk angka, maka data kuantitatif umumnya dikuantitatifkan agar dapat di proses lebih lanjut. Data yang diambil meliputi sejarah 
perusahaan, profil sumber daya manusia yang dimiliki, struktur organisasi, dan kegiatan sumber daya manusia; (b) Data kuantitatif adalah data yang diukur dalam suatu skala numerik (angka). Data yang diambil meliputi jumlah karyawan dan jumlah nasabah.

\subsection{Sumber Data}

Sumber data adalah data primer yang diambil dari 50 responden. Menurut Indriantoro (2002:146) sumber data dapat dibedakan menjadi 2 bagian, yaitu : Data primer merupakan sumber data penelitian yang diperoleh secara langsung dari sumber asli (tidak melalui media perantara) dan data sekunder merupakan sumber data penelitian yang diperoleh peneliti secara tidak langsung, melalui media perantara (diperoleh dan dicatat oleh pihak lain).

\subsection{Variabel Penelitian dan Pengukuran}

Sebagai alat ukur variabel (x) dan (y) yang digunakan adalah variabel skala likert.

Respon strategi perusahaan berupa investasi teknologi informasi yaitu dicerminkan dalam keinginan perusahaan untuk melakukan penambahan investasi dalam teknologi informasi. Firm Performance merupakan suatu ukuran yang menunjukkan output perusahaan, efisiensi, efektivitas; kekuatan dan kelemahan perusahaan; dan nilai perusahaan yang ditunjukkan dengan nilai saham perusahaan. Variabel ini diukur dengan objective measures yaitu nilai ROI dan ROA perusahaan yang diperoleh dan laporan keuangan.

\subsection{Metode Pengumpulan Data}

Metode yang digunakan dalam pengumpulan data untuk penelitian ini adalah metode penelitian lapangan yaitu data-data yang dikumpulkan dan tempat atau lapangan yang diselidiki yaitu di Kota Manado. Dalam penelitian ini digunakan beberapa metode di antaranya sebagai berikut: (1) Observasi, (2) Wawancara, (3) Kuesioner

\subsection{Metode Analisis}

Untuk menganalisis data yang telah díperoleh digunakan metode analisis data dalam penelitian yaitu analisis regresi linear sederhana. Menurut Dajan Anto (2002:315) bentuk persamaan regresi linear sederhana adalah: $\mathrm{Y}=\mathrm{a}+\mathrm{b} \mathrm{X}+\mathrm{e}$

Dimana:

$$
\begin{aligned}
& \mathrm{X}= \text { Variabel yang digunakan untuk menunjukkan investasi dalam } \\
& \text { teknologi informasi } \\
& \mathrm{Y}= \text { Variabel yang digunakan untuk menunjukkan tingkat kinerja perusahaan } \\
& \mathrm{a}= \text { Bilangan konstanta } \\
& \mathrm{b}=\text { Koefisien berganda }
\end{aligned}
$$

besar nilai a dan $\mathrm{b}$ dapat dihitung dengan cara :

$$
\mathrm{b}=\frac{\mathrm{n}\left(\sum \mathrm{XY}\right)-\left(\sum \mathrm{X}\right)\left(\sum \mathrm{Y}\right)}{\mathrm{n}\left(\sum \mathrm{X}\right)^{2}-\left(\sum \mathrm{Y}\right)^{2}}
$$

Kriteria pengujian yang digunakan adalah :

Apabila $t_{\text {hitung }}>\mathrm{t}_{\text {tabel }}$ atau signifikan $<\mathrm{a}=0,05$ maka Ho ditolak, Ha diterima

Apabila $\mathrm{t}_{\text {hitung }}<\mathrm{t}_{\text {tabel }}$ atau signifikan $>\mathrm{a}=0,05$ maka Ho diterima, Ha ditolak.

\subsection{Teknik Analisis}

Teknik analisis data yang digunakan dalam penelitian ini meliputi langkah-langkah sebagai berikut : (1) Mempelajari struktur organisasi dan pembagian kerja dalam perusahaan ; (2) Melakukan wawancara dengan pihak pimpinan perusahaan, manajer, dan staf di bidang teknologi informasi tentang penggunaan teknologi informasi dalam perusahaan ; ( 3) Mengetahui gambaran umum responden terhadap penggunaan teknologi informasi dalam kegiatan bisnis perusahaan ; (4) Menguji hipotesis untuk mengetahui pengaruh variabel (X) terhadap variabel (Y) ; (5) Membuat kesimpulan atas hasil penelitian dan kemudian memberikan saran-saran bagi kemajuan perusahaan. 


\section{HASIL PENELITIAN DAN PEMBAHASAN}

Kegiatan sewa guna usaha (leasing) diperkenalkan untuk pertama kalinya di Indonesia pada tahun 1974 dengan dikeluarkannya Surat Keputusan bersama Menteri Keuangan, Menteri Perdagangan dan Menteri Perindustrian No. Kep. 122/MK/2/1974, No. Kep-32/M/SK/2/1974 dan No, 30/Kep/1/74 tanggal; 7 Februari 1974 tentang "Perizinan Usaha Leasing". Sejak saat itu dan khususnya sejak tahun 1980 jumlah perusahaan sewa guna usaha, transaksi sewa guna usaha makin bertambah pesat dan meningkat dan tahun ke tahun untuk membiayai penyediaan barang-barang modal dunia usaha.

Hadirnya perusahaan sewa guna usaha patungan (joint venture) bersama perusahaan swasta nasional telah mampu mempopulerkan pernan kegiatan sewa guna usaha sebagai alternatif pembiayaan barang modal yang sangat dibutuhkan para pengusaha sebagai alternatif pembiayaan barang modal yang sangat dibutuhkan para pengusaha di Indonesia, disamping cara-cara pembiayaan konvensional yang lazim dilakukan melalui perbankan.

Sebelum dilakukan analisis regresi maka terlebih dahulu akan dilakukan uji validitas dan reliabilitas. Berikut akan disajikan hasil perhitungan uji validitas dan reliabilitas variabel Investasi Teknologi (X) dan uji validitas variabel kinerja perusahaan (Y) yang terdiri dari 10 pertanyaan. Dari uji reliabilitas variabel Investasi Teknologi $(\mathrm{X})$ diperoleh Alpha Cronbach $=0,861$ atau berada diatas nilai kritis yang disarankan sebesar 0,6 sehingga variabel Investasi Teknologi dinyatakan reliabel. Sedangkan dari uji reliabilitas variabel kinerja perusahaan (Y) diperoleh Alpha Cronbach =0,897 atau berada diatas nilai kritis yang disarankan sebesar 0,6 sehingga variabel kinerja perusahaan dinyatakan reliabel.

Dalam penelitian ini, pengujian hipotesis dilakukan untuk memastikan pengaruh respon perusahaan terhadap investasi Teknologi Informasi (TI) terhadap kinerja perusahaan. Analisis yang digunakan untuk hasil penelitian ini adalah statistik inferen berupa regresi linear sederhana, yaitu alat analisis peramalan nilai pengaruh satu variabel bebas terhadap satu variabel terikat untuk membuktikan ada tidaknya hubungan fungsional atau hubungan kausal antara variabel bebas dengan variabel terikat. Analisis data dilakukan dengan analisis regresi sederhana diperoleh persamaan sebagai berikut:

$$
\mathbf{Y}=\mathrm{a}+\mathrm{b} \mathbf{X}+\boldsymbol{\varepsilon}
$$

Dimana $\mathrm{Y}=$ Kinerja Perusahaan

$\mathrm{a}=$ Konstanta

$\mathrm{b}=$ Slope/koefisien regresi

$\mathrm{X}=$ Respon Perusahaan Terhadap Investasi Teknologi Informasi (TI). Nilai b yang merupakan koefisien korelasi sederhana dari variabel respon perusahaan terhadap investasi Teknologi Informasi (TI) (X) sebesar 0,987 mempunyai arti bahwa jika respon perusahaan terhadap investasi Teknologi Informasi (TI) bertambah 1 satuan, maka kinerja perusahaan akan mengalami kenaikan sebesar 0,987 satuan. Dengan demikian dapat diketahui bahwa setiap kali terjadi perubahan jumlah respon perusahaan terhadap investasi Teknologi Informasi (TI) maka akan mempengaruhi kinerja perusahaan.

Analisis koefisien korelasi (R) ini digunakan untuk mengukur keeratan hubungan antara variabel bebas $(\mathrm{X})$ terhadap variabel terikat $(\mathrm{Y})$, dalam hal ini mengukur kuat lemahnya hubungan respon perusahaan terhadap investasi Teknologi Informasi (TI) sebagai variabel $\mathrm{X}$ dengan kinerja perusahaan sebagai variabel $\mathrm{Y}$, sedangkan koefisien determinasi $\left(\mathrm{R}^{2}\right)$ diperlukan untuk mengukur seberapa besar pengaruh respon perusahaan terhadap investasi Teknologi Informasi (TI) (X) terhadap kinerja perusahaan (Y).

Hasil analisis regresi menghasilkan koefisien korelasi (R) sebesar 0,905 atau 90,5\% dan ini menunjukkan hubungan yang sangat kuat antara respon perusahaan terhadap investasi Teknologi Informasi (TI) dengan kinerja perusahaan.

Nilai Koefisien Penentu atau Koefisien Determinasi sebesar 0,818216 atau 81,821 \% ini memberikan pengertian bahwa variasi (naik/turunnya) kinerja perusahaan yang disebabkan oleh 
investasi Teknologi Informasi (TI) adalah 81,821 \%, sedangkan selebihnya disebabkan oleh faktorfaktor lain (variabel lain) diluar model ini.

Hasil analisis regresi menggunakan $t_{\text {hitung }}=14,694>t_{\text {tabel }}=2,92$ dengan signifikan $=0,000<$ 0,05, maka dapat disimpulkan bahwa $\mathrm{H}_{0}$ ditolak atau $\mathrm{H}_{\mathrm{a}}$ diterima. Ini berarti bahwa respon perusahaan terhadap investasi Teknologi Informasi (TI) berpengaruh terhadap kinerja perusahaan.

Dalam penelitian ini yang ditekankan oleh penulis adalah peningkatan kinerja perusahaan dalam bentuk organisasi melalui penggunaan dan investasi dalam teknologi informasi. Menempatkan profesionalisme sebagai upaya untuk memenangkan persaingan, dengan meningkatkan kualitas dan seluruh personil atau karyawan dari semua level.

Anggapan umum selama ini aset perusahaan yang berharga adalah gedung kantor, investasi dan sumber daya manusia terutama dalam perusahaan finance. Namun persepsi ini telah bergeser seiring dengan era globalisasi yang sebentar lagi akan kita masuki. Dalam penelitian ini hasil yang diperoleh bahwa daya manusia yang bermutu akan semakin berkualitas apabila didukung dengan teknologi informasi yang memadai. Teknologi informasi perusahaan muncul sebagai salah satu aset perusahaan dalam mencapai tujuan perusahaan. Pada dasamya setiap perusahaan pasti menginginkan kinerja terbaik dari seluruh karyawan. Dengan adanya teknologi informasi akan mempermudah para karyawan untuk meningkatkan kinerja perusahaan dalam mencapai tujuan perusahaan.

Perusahaan Finance harus memperhatikan faktor-faktor yang mempengaruhi investasi dalam teknologi informasi terhadap peningkatan kinerja. Berdasarkan hasil penelitian diperoleh persamaan regresi linear sederhana antara nilai teknologi informasi terhadap kinerja adalah $\mathrm{Y}=0,987 \mathrm{X}+\boldsymbol{\varepsilon}$. Persamaan ini memberi arti bahwa jika respon perusahaan terhadap investasi Teknologi Informasi (TI) bertambah 1 satuan, maka kinerja perusahaan akan mengalami kenaikan sebesar 0,987 satuan. Dengan demikian diketahui bahwa setiap kali terjadi perubahan jumlah respon perusahaan terhadap investasi Teknologi Informasi (TI), maka akan mempengaruhi kinerja perusahaan. Hasil analisis regresi menghasilkan koefisien korelasi (R) sebesar 0,905 atau 90,5 \% ini menunjukan hubungan yang sangat kuat antara respon perusahaan terhadap investasi Teknologi Informasi (TI) dengan kinerja perusahaan. Besarnya kinerja perusahaan yaitu respon perusahaan terhadap investasi Teknologi Informasi (TI) ditunjuk oleh koefisien determinasi (R2) sebesar 0,81821 atau 81,821\%, dan sisanya 18,2 \% dipengaruhi oleh faktor-faktor lain yang tidak diteliti.

Berdasarkan persamaan regresi linier sederhana di atas yang memberi arti bahwa setiap penambahan teknologi informasi sebesar 1 akan meningkatkan kinerja sebesar 0,987 dan hasil tersebut, maka hubungan antara nilai teknologi informasi dan kinerja adalah kuat positif. Pernyataan ini lebih jelas lagi didukung dan dibuktikan dengan hasil pengujian hipotesis yang diperoleh $\mathrm{t}$ hitung $=14,694>\mathrm{t}$ tabel $=2,92$ dengan tingkat signifikan $=0,05$ maka, Ho ditolak atau Ha diterima. Secara jelas telah diperoleh bahwa respon perusahaan terhadap investasi teknologi Informasi berpengaruh terhadap kinerja perusahaan.

\section{KESIMPULAN}

Berdasarkan hasil penelitian yang dilakukan pada perusahaan finance maka dapat disimpulkan oleh penulis sebagai berikut : Berdasarkan hasil uji hipotesis dengan uji regresi linear sederhana dapat diketahui bahwa apabila respon perusahaan terhadap investasi Teknologi Informasi (TI) bertambah 1 satuan, maka kinerja perusahaan akan mengalami kenaikan sebesar 0,987 satuan. Dengan demikian dapat diketahui bahwa setiap kali terjadi perubahan jumlah respon perusahaan terhadap investasi Teknologi Informasi (TI) maka akan mempengaruhi kinerja perusahaan. Dari hasil uji koefisien korelasi (R) sebesar 0,905 atau 90,5\% ini menunjukkan hubungan yang sangat kuat antara respon perusahaan terhadap investasi Teknologi Informasi (TI) dengan kinerja perusahaan. Sedangkan koefisien determinasi (R2) adalah sebesar 0,81821 ini menggambarkan bahwa besarnya kinerja perusahaan yang dapat dijelaskan oleh variabel independen yaitu respon perusahaan terhadap investasi 
Teknologi Informasi (TI) adalah sebesar $81,8 \%$, sementara sisanya di jelaskan oleh variabel lain diluar model ini.

Hasil analisis regresi menggunakan uji $t$ didapat $t_{\text {hitung }}=14,694>t_{\text {tabel }}=2,92$ dengan tingkat signifikan $=0,000<0,05$, maka dapat disimpulkan bahwa $\mathrm{H}_{0}$ ditolak atau $\mathrm{H}_{\mathrm{a}}$ diterima. Ini berarti bahwa respon perusahaan terhadap investasi Teknologi Informasi (TI) berpengaruh terhadap kinerja perusahaan.

\section{DAFTAR PUSTAKA}

Gitasudarmono I, Pengantar Bisnis, Gelora Aksara Pertama, Jakarta, 2000. hal.71

Jumaili Salman, Kepercayaan Terhadap Teknologi Sistem Informasi Baru dalam Evaluasi Kinerja Individual, SNA VIII, Solo, 2005. hal. 109

Kadir A, Pengenalan Sistem Informasi, Andi, Yogyakarta, 2003. hal. 36

Kristanto A, Perancangan Sistem Informasi dan Aplikasinya, Gava Media, Yogyakarta, 2003. hal. 77

Ladyamudin, Analisis Sistem Informasi, Graha Ilmu, Yogyakarta, 2005. hal. 42

Luthan F, Perilaku Organisasi, Edisi 10 Andi, Yogyakarta, 2006

Mangkunegara A, Evaluasi Kinerja Sumber Daya Manusia,Refika Aditama, Bandung, 2005. hal. 31

Purwanto Djoko, Komunikasi Bisnis, Erlangga, Jakarta, 2003. hal.101

Riduwan dan Akdon, Rumus dan Data dalam Analisis Statistika, Alfabeta, Bandung, 2010. hal.133

Romney B dan Steibert Paul, Accounting Information System, Salemba Empat, Jakarta, 2003. p.56

Siagian P, Teori Pengembangan Organisasi, Bumi Aksara, Jakarta, 2004. hal. 123

Simamora H, Akuntansi Bisnis Pengambilan Keputusan Bisnis, UPP AMP YKPN, Yogyakarta, 2002. hal.102

Suliyanto, Analisis Data dalam Aplikasi Pemasaran, Ghalia Indonesia, Purwokerto, 2005. hal.62

Wahana, Panduan Aktif Sistem Informasi Akuntansi Online Berbasis Komputer, Andi, Yogyakarta, 2003. hal.84

Nugroho W, Sistem Informasi Akuntansi, Erlangga, Jakarta, 2001. hal.86

Witarto, Memahami Sistem Informasi, Informatika, Bandung, 2004. hal.91 